\title{
Employee Retention in Nepalese Commercial Banks
}

\begin{abstract}
Dhan Raj Chalise*
Abstract

Employee retention issues is the burning issues especially in the banking sector in Nepal. This study is designed to examine the factors on retention of employees in Nepalese commercial bank. Adopting descriptive cum analytical research design the study is based on 5 point likert scale questionnaire. 200 managers, assistant manager and officers level employees from three commercial bank operating at Kathmandu valley were selected on basis of stratified random sampling method. Training and Development, Career Opportunity and Work Lifer policies are taken as dependent and Employee retention as an Independent variable of the Study. The collected data were analyzed through correlation, regression and coefficient analysis to establish the relationship between the dependent and independent variables. The result showed a significant positive relationship between career opportunities, work life policy with employee retention. In addition this study replicates the high level of effect of work life policy and no significant relationship with training and development program in Nepalese commercial banks.
\end{abstract}

Key Word: Training and Development, Work Life Policies, Career Opportunities, Employee Retention, Commercial Bank

\section{Introduction}

Changes within the economic environment have impacted both the formal and informal contracts of employment which has affected employee motivation and organizational obligation. Turnover rate results the entire loss for organization is at a loss when the workers leave their job once they're fully trained. Employee retention takes under consideration the assorted measures taken in order that a personal stays in a corporation for the utmost period of your time. One among the most reasons behind employee's turnover is because of lack of job-satisfaction (Ragupathi, 2013). Therefore, it's essential for organization managers to take a position their time in addressing employee dissatisfaction. There are many human resource strategies provided to retain employees for the advantage of the organizations. These strategies are aimed toward avoiding turnover rate. Employee retention implies the means, plan or set of deciding behavior put in situ by organizations to retain their competent workforce for performance (Gberevbie, 2008). However, recent studies have shown that

* Mr. Chalise is Lecturer at Tribhuvan University, Faculty of Management, Shanker Dev Campus. Email: Chalisedr@gmail.com 
retention of highly skilled employee became a difficult task for managers, as this category of employees are being attracted by over one organization at a time with various varieties of incentives (Micheal, 2009).

Human resources is an increasingly expansion term with which a corporation, or other human system describes the mix of traditionally administrative personnel functions with acquisition and application of skills, knowledge and skill, employee relations and resource planning at various levels. This sector draws upon concepts developed in Industrial/ Organizational Psychology and System Theory. Human resources have a minimum of two related interpretations betting on context. Employee retention implies the means, plan or set of deciding behavior put in place by organizations to retain their competent workforce for performance (Gberevbie, 2008). There are many human resource strategies provided to retain employees for the advantage of the organizations. These strategies are aimed toward avoiding turnover rate.

\section{Statement of Problem}

Employees turnover is one among which are considered to be one among the challenging issues in business now a days. The impact of turnover has received a substantial attention by senior management, human resources professionals and industrial psychologists. It's proven to be one among the foremost costly and seemingly intractable human resource challenges confronting by several organizations globally. Training could be a planned effort by the corporate to facilitate employees learning of job-related competencies (Noe et al, 2003). Investment on employee training and development opportunity is taken into account important think about employee retention. Organization has incentive to form expect to return and provides output on its investment (Messmer, 2000).

The career progression is a meeting which is meant and designed to cater the wants of employees associated with their career furthermore because the organizations' expectation from its human capital in order that both are able to do maximum level of satisfaction. (Hackman \& Oldham, 1976) in their study found an in depth and correlational statistics between promotions and job satisfaction and which successively helps in retaining employees. The businesses need competent workers which lead them to the trail of success for the future on the opposite hand the workers need good opportunities for bright and glowing career (Sutherland, 2004). It is the human resource department which has huge responsibility on its shoulders to formulate such plans and techniques that instigate that employees loyalty toward the goals and objectives of the firm in order that employees get inspired and work effortlessly positively within the favor of the corporate and keep the corporate within the list of top companies (Graddick, 1988). The corporate which needs strong and positive relations with its workers must do much within the favor of the workers and for his or her betterment (Samuel \& Chipunza, 2009).

An employee likes to work an area, where he's given a correct environment to figure. Many companies are providing flexible schedules and work arrangements and are experimenting 
with other ways to assist individuals manage their work and private life issues (Perry-Smith\& Blum, 2000). Employees are being rewarded with significance and are given magnitude due to a balance work-life plan. a number of the workers are loyal with the corporate and that they don't consider switching the roles they're engaged in. they're mostly fearful of the schedule of their work because sometimes the work effect their personal and social life but they struggle to balance but those employees who are within the hunt of a brand new job show different attitude (Dubie, 2000). Many researchers are performing on the contact between the work and also the family issues that if both of them are plagued by one another or not a number of these issues are the straightforward working hours, taking care of the children's, parental leaves information regarding child care and leaves with commitment of the organization. Research has notified that the organizations show high level of loyalty if the workers must face worklife plans. Employees expect a piece environment, where they'll utilize their abilities and satisfy their basic needs. Work environment is one among the factors that affect employee's decision to remain with the organization (Nazim, 2008).

Employee turnover could be a problem for entrepreneurs round the world (Rana 2015). The matter appears to be even more burdensome to Nepali entrepreneurs because it is incredibly difficult to search out talent within the market; retaining them is even more of a challenge. Instead of losing employees to a competitor, there's a better likelihood of losing them to the upper paying non-profit sector or the worker going abroad to pursue further education. For startups, retaining employees can pose even greater problems as Nepali culture promotes safety when it involves careers. As a result, young graduates are lighter finding jobs in larger corporations like banks and business house. Commercial banks have provided employment to 27,908 numbers of people as of mid-July 2017 , which is $17.8 \%$ increment in comparison to total employment of 23,692 of last year (NRB 2018). Banks face plenty of problems relating employee retention now every day. As employees are the foremost precious and important asset of a corporation, so, organization should take measures to encourage employees to stay in the organization for the maximum period of time. It is because when an employee leaves an organization then it incurs a huge loss and an unbalanced situation to the internal environment of the organization. The case of high turnover is frequently observed in Nepalese organization and the rate is found even more in banking sector. Although this sector is characterized by higher professionalism than other, retention of employee is the challenge faced by the banks. In view of this context and reality, this study is going to be undertaken to explore the factors facilitating higher retention in organizations. It is directed towards exploring the answers of following questions.

- How is the relationship between training \& development and employee retention?

- Is there significant relations between career opportunities and employee retention?

- Whether the work life policies has impact on employee retention?

\section{Objectives of Research}

This study aims to explore the determinants of employee retention taking the reference of Nepalese banking sector. The followings are the specific objectives of the study. 
- To examine relation between training \& development and employee retention.

- To identify relation between career opportunities and employee retention.

- To extract relation between work life policies and employee retention.

\section{Research Hypothesis}

This research has following hypothesis:

H1: There is significant relation between training \& development and employee retention.

$\mathrm{H} 2$ : There is significant relation between career opportunities and employee retention.

H3: There is significant relation between work life policies and employee retention.

\section{Review of Literature}

Human resource management practices in compensation \& rewards, job security, training \& developments, supervisor support culture, work environment and organization justice can help to cut back absenteeism, employee retention and better quality work. Glen (2006), describes a framework, manager can use when communicating with its employees to grasp that the reason for retention include nine different predictors: organizational processes, role challenge, values, work life balance, information, stake/leverage/recognition, management, work environment and products or service. The workers will be retained in a company once they are given adequate information regarding their work the corporate. They must be given different roles and challenges so they will come front with various ideas for the upliftment of the organization. The organization has to give their employees duly recognition for his or her work so they gets motivated and might work with flexibility in a very friendly environment for the betterment of themselves and organization at large. Retention means an obligation to still do business or exchange with a selected company on an ongoing basis (Borstroff, 2007). If the corporate isn't ready to retain its employees, it'll not be ready to make the most human assets developed within the organization. In today's context no any employees will persist with organization for extended period of time, which the management has to identify the workers who have longer commitment towards the organization and specialize in the retention strategies to create them stay for extended period within the company. These strategies could also be associated with compensation, higher cognitive process, and suppleness in working environment.

\section{Determinants of employee retention Training \& Development opportunities}

Investment on employee training and development opportunity is taken into account important consider employee retention. Organization has incentive to create expect to return and provides output on its investment (Messmer, 2000). Training is defined by Noe et al. (2003) as a planned effort by the corporate to facilitate employees learning of job-related competencies. The aim of coaching is for workers to master knowledge, skills and behaviors, which are emphasized in training, and apply them to their day-to-day activities. Conversely, development refers to formal education, job experiences, relationships and assessment of personality and talents that help employees to organize for the longer term (Noe et al., 2003). 
Organization where employees receive proper training that's necessary to assume greater responsibilities, turnover rates are generally lower (Moncarz \& Kay, 2009).

\section{Career opportunities}

Career opportunities The career progression is a rendezvous which is meant and designed to cater the wants of employees associated with their career similarly because the organizations' expectation from its human capital so both are able to do maximum level of satisfaction. The enhancement in awareness makes it obvious that the ability of individuals can only take a company to the highest level. It's the human resource department which has huge responsibility on its shoulders to formulate such plans and methods that instigate that employee's loyalty toward the goals and objectives of the firm so employees get inspired and work effortlessly positively within the favor of the corporate and keep the corporate within the list of top companies (Graddick, 1988). The corporate which needs strong and positive relations with its workers must should do much within the favor of the workers and for his or her betterment (Rentsch \& Steel, 1998). The businesses need competent workers which lead them to the trail of success for the future on the opposite hand the workers need good opportunities for bright and glowing career (Prince, 2005).

\section{Work-Life Policies}

Employees are being rewarded with significance and are given magnitude due to a balance work-life plan. a number of the workers are loyal with the corporate and that they don't consider switching the roles they're engaged in. they're mostly frightened of the schedule of their work because every now and then the work effect their personal and social life but they fight to balance but those employees who are within the hunt of a brand new job show different attitude (Dubie, 2000). Many researchers are acting on the contact between the work and also the family issues that if both of them are suffering from one another or not a number of these issues are the straightforward working hours, taking care of the children's, parental leaves information regarding child care and leaves with commitment of the organization. Research has notified that the organizations show high level of loyalty if the workers should face work-life plans.

\section{Theoretical Framework}

This framework is presented based on the determinants of employee retention deduced from the review of literature. The framework shows that employee retention as a dependent variable on training and development, career opportunities and work life policies. 
Figure 1: Conceptual Framework of the Study

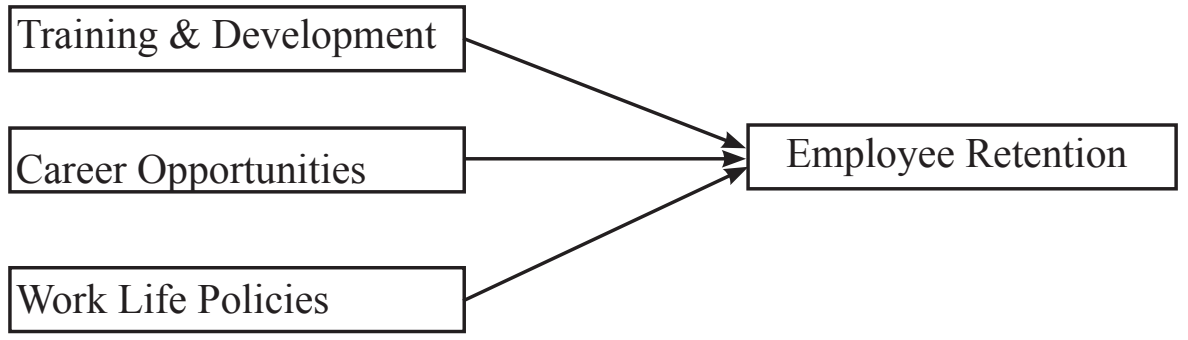

\section{Research Methodology}

The study has focused on determining the determinants of retention of employees from Prabhu bank, Rastriya Banijya Bank and Century Bank located at Kathmandu. The study is based on both descriptive and exploratory research design. All the employee working in commercial bank are taken as population for the study. 200 respondent of Manger, Assistant Manager and officer's level employee from three commercial bank were selected as a sample on stratified random sampling method and 175 questionnaire were found return with usable form. Primary data were collected through five point Likert scales questionnaire anchored by 1 (strongly agree) and 5 (strongly disagree). The data collected from the questionnaires is completely summarized and analyzed by using Statistical Package for Social Science (SPSS). Frequency and descriptive analysis has been carried out. Pearson's correlation coefficient and multiple regression analysis is used to analyze the relationship and extent of effect between and among the independent and dependent variables.

\section{Result and Discussion Descriptive Analysis}

Table 1 shows that all together 175 respondent were participated for the study. Among them the majority of the respondents (60 percent) were male and about 40 percent respond represent from female employees.

Table 1: Gender wise distribution of the respondents

\begin{tabular}{|l|c|c|}
\hline Gender & Frequency & Percent \\
\hline Male & 105 & 60 \\
\hline Female & 70 & 40 \\
\hline Total & 175 & 100 \\
\hline
\end{tabular}

Source: Field Survey (2019)

With respect to the age wise distribution, the majority of the respondent falls in the age group of 30 to 39 followed by 20 to 29 by representing 35 and 32 percent respectively. Similarly, the respondents of age group of 40 to 49 and above 50 found of 18 and 15 percent respectively shows in table 2. 
Table 2. Age wise distribution of the respondents

\begin{tabular}{|l|l|l|}
\hline Age & Frequency & Percent \\
\hline 20 to 29 & 53 & 32 \\
\hline 30 to 39 & 61 & 35 \\
\hline 40 to 49 & 33 & 18 \\
\hline 50 and above & 28 & 15 \\
\hline Total & 175 & 100 \\
\hline
\end{tabular}

Source: Field Survey (2019)

Table 3 shows the majority of the respondent falls in the category having experience of five to ten years, which is about 45 percent of the total respondents. The respondents having more than ten years' experience and up to five years' experience are 33 percent and about 22 percent respectively.

Table 3: Experience wise distribution of the respondents

\begin{tabular}{|l|l|l|}
\hline Experience & Frequency & Percent \\
\hline 5 years & 38 & 22 \\
\hline $5-10$ years & 80 & 45 \\
\hline 10 years above & 57 & 33 \\
\hline Total & 175 & 100.0 \\
\hline
\end{tabular}

Source: Field Survey (2019)

Five attributes under retention practices were taken for the study. Among the five attribute taken to measure the retention practices performance of an organization highly depends upon employee turnover has the highest mean of 3.9811 with standard deviation of approximately 1.12. Among the six attributes under the variable Training and Development the major factor for the effective performance of the employees has the highest mean of 3.779 implies that the employees consider $\mathrm{T} \& \mathrm{D}$ to be one of the major factor for the effective performance for the employee retention program at highest level. Among the five attribute of career opportunity work environment is sound and appropriate to motivate you to work has the highest mean of 3.6427 and standard deviation of 0.8743 states that the employees are satisfied with working environment of their organization. Similarly under the work life policies variable three attributes were taken where Employee by rules of the bank is supportive towards the employees has highest men of 4.22 with standard deviation 0.4982 shows the employee are satisfied with the banking rule. Among the three attribute working beyond the office hour has the highest mean of 4.0390 with the scale of minimum 1 to maximum of 5 . This states that the employees are not satisfied with the working hours and might be one of the reasons for employee not being retained. 
Correlation Analysis

Table 4: Correlation Analysis

\begin{tabular}{|l|l|l|l|l|}
\hline & T\&D & C O & W L P & ER \\
\hline T\&D & 1 & & & \\
\hline C O & $.825^{* *}$ & 1 & & \\
\hline W L P & $.473^{* *}$ & $.451^{* *}$ & 1 & \\
\hline ER & $.421^{* *}$ & $.471^{* *}$ & $.399^{* *}$ & 1 \\
\hline
\end{tabular}

${ }^{* *}$ Correlation is significant at 0.01 level $(2$ - tailed $)$

Where, $\mathrm{T} \& \mathrm{D}=$ Training and Development, $\mathrm{CO}=$ Career Opportunity, WLP= Work Life Policies and ER. $=$ Employee Retention

The correlation tables indicates the relationship between employee retention with training and development, career opportunity and work life policy. The correlation coefficient between employee retention and the training and development was found to be 421 which is positively correlated. Similarly employee retention with the career opportunity and work life policy was also found positive correlation with $\mathrm{r}=471$ and $\mathrm{r}=451$ respectively Thus it can be concluded that there is a positive and significant relationship between employee retention with independent variable under study.

\section{Regression Analysis}

In multiple regression analysis, all of the independent variables regressed on the selected explanatory variables to find out their significance in explaining the changes on the dependent variables for the employee retention in commercial banks of Nepal.

Table 5: Result of Regression Analysis

\begin{tabular}{|l|l|l|l|}
\hline & Beta & Sig. & t-value \\
\hline Constant & $(0.19)$ & 0.42 & $(0.72)$ \\
\hline Training and development & $(0.17)$ & 0.19 & $(1.65)$ \\
\hline Career opportunity & 0.12 & 0.01 & 4.11 \\
\hline Work life policy & 0.29 & 0.00 & 3.17 \\
\hline
\end{tabular}

Adjusted R Square $=0.48$, F-Value $=19.75$, Sig $=0.000$

On the basis of above findings following regression model has been developed: $E R=(0.19)$ $0.17 X 1+0.12 \times 2+0.29 X 3$

Where, ER= Employee Retention, $\mathrm{X} 1=$ Training and Development, $\mathrm{X} 2=$ Career Opportunity and $\mathrm{X} 3=$ Work life Policies.

Regression analysis in table 5 shows the relationship between the dependent variables and the independent variables. According to the significant value, career opportunity and work life policies are significant in determining the employee retention program at the commercial 
banks in Nepal. Regression coefficient of employee retention is highly determined by work life policy provided by the organization and is 0.29 which indicates that if the organization increases the tendency of work life policy by a unit then the employee retention possibility is increased by 0.29 times. Similarly regression coefficient of employee retention is highly determined by career opportunity provided to its staffs the value is 0.12 which indicates that if the organization increases the tendency of support by a unit then the employee retention possibility is increased by 0.12 times.

\section{Relationship between training \& development and employee retention.}

As shown in the table 2, training and development was not found to provide the major contribution towards the employee retention program at the commercial banks of Nepal at p-value of 0.19 ( $p>0.05)$, thus failed to reject the null hypothesis. Therefore it is concluded that there is no significant relationship between training and development and employee retention.

\section{Relationship between career opportunities and employee retention.}

As shown in the table 2, career opportunity was found one of the factor contributing towards the employee retention program at the commercial banks of Nepal at p-value of $0.01(\mathrm{p}<0.05)$, thus $\mathrm{H} 2$ was accepted. Therefore it is concluded that there is significant relationship between career opportunities and employee retention.

\section{Relationship between work life policies and employee retention.}

As shown in the table 2, work life policies was found to provide the major contribution towards the employee retention program at the commercial banks of Nepal at p-value of 0.00 ( $p<0.05)$, thus H3 was Accepted. Therefore it is concluded that there is a significant relationship between work life policies and employee retention.

\section{Conclusion and Implication}

The findings of the research states that the commercial banks are able to retain their employees through various facilities and services as provided like better work environment, promotions, salary and benefits, opportunity, the training and development programs and other facilities like supporting environment from its stockholder. Most of the employee left their job getting better opportunity in similar organizations. The study shows that employee seek another job in regards to make the future career better. Nepalese commercial banks are designed and provided different employee welfare package to discourage the employee turnover however retaining their best employees by providing necessary benefits and by observing the effectiveness and effort of the employees, there found discouraging environment. One of the possible reason for high employer turnover in the bank may due to considering training and development as main factor for employee satisfaction. But this study found it has no effect on employee retaining. 
There are many factors that determine the retention ratio of employees at the banks but with the limitation of time period the observed factors in the research have shown positive impact over employee retention strategy and these are the factors influencing the retention level. The result has shown positive and significant contribution by the influencing factors such as career opportunity and work life policy. Career growth, job description, remuneration, job security and other factors need to be considered well design to motivate and retain employee in the banking industry. The Nepalese commercial banks need to focus on organizational career growth policy and should create solid sentiments of a psychological contract among employees especially when the organizational career growth policy of the organization is a valuable attempt for its employees who anticipate progress and growth in their careers. In addition it is recommended that appropriate career planning and work life matching package need to be develop so that bank employees may produce their better result for the organization.

\section{Limitations of the Study}

The study has covered only two commercial banks in Nepal. Therefore the finding of the study cannot be generalized for the entire commercial banking industry. Only three independent variables training and development opportunities, career opportunity and work life policies have been considered in the study. The study is primarily based on questionnaire method of data collection. Therefore limitations of these methods are also remained in the study. The sample of the study are taken the employees working in Kathmandu only, hence the finding may be generalized with due consideration.

\section{Reference}

Bank Supervision Report (2017). Nepal Rastra Bank, Bank Supervision Department Baluwatar, Kathmandu, Nepal. April 2018

Borstroff, P. C. (2007). Turnover drivers and retention factors affecting hourly workers. Management Review: 2, 14-27.

Branham, L. (2005). Planning to become an employer of choice. Journal of Organizational Excellence, 24, 57-68.

Dubie, D. (2000). Should you stay or should you go? Network World, 17(29), 66.

Eisenberger ,R., Huntington, R., Hutchison, S., \& Sowa, D. (1986). Perceived organizational support. Journal of Applied Psychology, 71(3), 500-507.

Gberevbie, D. E. (2008). Staff recruitment, retention strategies and performance of selected public and private organizations in Nigeria. (Unpublished Doctoral Thesis) Convenant University, Ota. 
Glen, C. (2006). Key skills retention and motivation: the war for talent still rages and retention is the high ground. Industrial and Commercial Training, 38(1), 3745. doi:10.1108/00197850610646034

Graddick, M. N. (1988). Corporate philosophies of employee development, career growth and human resource strategies: The role of the human resource professional in employee development London, M. \& Mone, E.M. (Eds B), Quorum Books, Westport, CT.

Hackman, J. R., \& Oldham, G. R. (1976). Motivation through the design of work: Test of a theory. Journal of Organizational Behavior and Human Performance.16, 250-279.

Howard K. Wolf, Pant, P.R. (2007). Social Science Research and Thesis Writing. Kathmandu: Buddha Academic Enterprise Pvt. Ltd.

Messmer, M. (2000). Orientation programs can be key to employee retention. Strategic Finance, (8) $12-15$.

Messmer, M. (2000). Orientation programs can be key to employee retention. Strategic Finance, 81(8)20-23.

Micheal, O.S. (2009). Employee retention and turnover: Using motivational variables as Panacea. African Journal of Business Management, 3(8).410-415.

Moncarz, E., Zhao, J., \& Kay, C. (2009). An exploratory study of US lodging properties' organizational practices on employee turnover and retention. International Journal of Contemporary Hospitality Management, 21(4), 437-458. doi:10.1108/09596110910955695

Nazim Ali, Q. B. (2008). Impact of job satisfaction on turnover intention: An empirical evidence. Journal of Managerial Sciences.2 (1), 24-28.

Noe, R., Hollenbeck, J., Gerhart, B., \&Wright, P. (2003). Human resource management: gaining a competitive advantage (4thed.), Boston: McGraw Hill.

Prince, B. J. (2005). Career-focused employee transfer processes. Career Development International, 10, (4) 293-309.

Ragupathi, D. (2013). The employee retention practices of MNC'S in Hyderabad. Research Journal of Management Sciences.2 (4), 21-24.

Rana, V. (2015). Retaining employees at a Startup: A Nepali context. https://ventureplus. com.np/retaining-employees-at-a-startup-a-nepali-context/

Rentsch, J. R. \&Steel, R.P. (1998).Testing the durability of job characteristics as predictors of absenteeism over a six-year period. Personnel Psychology, 51(1), 165-190. 
Samuel, M., \& Chipunza,C.(2009). Employee retention and turnover: Using motivational variables as a panacea. African Journal of Business, 3, (8) 410-415.

Sutherland, M., \& Jordaan, W. (2004). Factors Affecting the Retention of Knowledge Workers. SA Journal of Human Resource Management, (2). doi:10.4102/sajhrm.v2i2.39 